\title{
From the Brazilian semiarid to university: the incorporation of a Cooperative Learning project as academic extension
}

\author{
Bruno de Souza Lessa ${ }^{*}$, Ana Clara Aparecida Alves de Souza² and José Carlos Lázaro da Silva-Filho
}

${ }^{*}$ Correspondence: brunolessa85@yahoo.com.br

${ }^{1}$ Universidade Federal

do Ceará, Avenida da

Universidade, 2431

Benfica, Fortaleza, Ceará,

Brazil

Full list of author information is available at the end of the article

\begin{abstract}
The interaction between university and its surrounding communities is vital for society. The incorporation of social initiatives as formal university extension programs can tackle different social demands, strengthening the "extension" pillar of the tripod that underpins Brazilian universities. The Program of Education in Cooperative Cells (PRECE, in Portuguese) has been preparing students from the semiarid region to face the entrance exam of the Federal University of Ceará (UFC, in Portuguese). PRECE was idealized by a group of youngsters living in the semiarid region of the state, in the municipality of Pentecoste. This study had the objective to evidence PRECE's trajectory, foregrounding its incorporation as an extension program by the UFC. This research was qualitative, analyzing the program and its relationship with the University. Interviews were performed with the managerial team and with people in charge of its coordination as a university extension program. In this sense, the study sought to identify the essential elements for Cooperative Learning suggested by Johnson and Johnson (Asia Pac J Educ 22:95-105, 2002). The findings brought forward the trajectory enabling the incorporation of PRECE as an extension program and its alignment with Cooperative Learning essential elements. The research contributes with the reflection about the factors necessary to integrate university and community through the assimilation of social initiatives.
\end{abstract}

Keywords: Education, Cooperative Learning, Cooperation, University, Extension

\section{Introduction}

The development of social competences, besides academic ones, is increasingly important once it is essential for students to learn how to interact and cooperate. Since the 1970s, the use of Cooperative Learning as a pedagogical tool has been broadly studied and its use has been proved effective in classroom (Artzt and Newman 1997; Leikin and Zaslavsky 1999; Gillies 2003; Peterson and Miller 2004; Hennessey and Dionigi 2013).

Gillies and Boyle (2010) affirm that, in several moments, students are assembled in classroom situations leading to a loss of the opportunity to harvest the benefits of interacting with one another.

According to Hsiung et al. (2014), in Cooperative Learning the main objective for students is to work as team to maximize academic success of all members. Among other responsibilities, students must study and exercise interpersonal abilities together.

(C) 2016 de Souza Lessa et al. This article is distributed under the terms of the Creative Commons Attribution 4.0 International License (http://creativecommons.org/licenses/by/4.0/), which permits unrestricted use, distribution, and reproduction in any medium, provided you give appropriate credit to the original author(s) and the source, provide a link to the Creative Commons license, and indicate if changes were made. 
Regarding the use of Cooperative Learning in Brazil, an initiative called Programa de Educação em Células Cooperativas (PRECE-Program of Education in Cooperative Cells in Portuguese) has been operating with CL elements for more than two decades, helping individuals from the poor semiarid region of Ceará, a state located in the Brazilian northeast, to go to university. The initiative's success is represented by the approval of many of its members in different universities as well as by their entrance in post-graduation programs. Aiming at contributing with such successful initiative, the Federal University of Ceará (hereby called by its Portuguese acronym UFC) incorporated PRECE as an extension program (PRECE 2015). In 2009, UFC created the Program of Cooperative Learning in Cells with the goal to improve students' learning, increase graduation rates and reduce evasion. Besides that, the State Secretary of Education established a partnership with PRECE to diffuse CL across high school students and teachers (PRECE 2015).

This study has the general objective to highlight PRECE's trajectory, its incorporation as an extension program by UFC and from this general objective emanated three specific ones. First, to identify elements in PRECE's trajectory that made possible its incorporation as a UFC's extension program. Second, to analyze how CL has been used in the extension program as a learning tool to reach its goals. Third, to verify the alignment of the practice performed in the Cooperative Learning five elements: (Johnson and Johnson 2002): positive interdependence, individual accountability, promotive interaction, use of interpersonal and small-group skills and group processing.

Therefore, this paper's contribution is threefold. First, it presents an initiative that has been empowering students from vulnerable social conditions and its incorporation as an extension program by a public university. Second, it shows how an alternative form of learning has been functioning in the Brazilian undergraduate sphere. At last, it demonstrates how the establishment of such partnership has been fruitful for the stakeholders involved and the extent of its effectiveness, aligned with Johnson and Johnson (2002).

\section{Background}

\section{Cooperative Learning}

In their early history, human beings started coordinating in groups to facilitate how different tasks would be drafted. The need to survive implied in cooperation; and, consequently, in fostering solidarity bonds (Jaguaribe 2001).

In the last decades of the 19th century and early 20th, the North American movement defending universal education known as "Common School Movement" intensified and expanded the use of study groups based on cooperative ideas. At this point, authors such as Parker and John Dewey might be evidenced as the main exponents (Johnson and Johnson 1989).

Stahl (1994) stresses that even with the rising adhesion to the Cooperative Learning methodology; most tasks developed by groups of teachers (including those who claim to be adopting Cooperative Learning) continue to be non-cooperative group activities. This author foregrounds that to be characterized as Cooperative Learning the method must adopt some essential classroom elements, such as a clear set of specific student learning. All students in the group "buy into" the targeted outcome; Clear and complete set of task-completion directions; Heterogeneous groups; Equal opportunity for success; Positive interdependence; Face-to-face interaction; Positive social interaction behaviors 
and attitudes; Access to must-learn information; Opportunities to complete required information-processing tasks; Sufficient time is spent learning; Individual accountability; Public recognition and rewards for group academic success; Post-group reflection (or debriefing) on within-group behaviors.

In accordance with Prince (2004), although there are different Cooperative Learning models, there is a common central element regarding the focus on incentives to cooperate in order to promote learning. In this sense, it is highlighted that the essence of Cooperative Learning lies in the fact that cooperation is more effective than competition among students seeking positive learning outcomes.

\section{Pedagogical foundations: competition versus cooperation}

To foster cooperation and to be considered as a practice within the realm of Cooperative Learning, a pedagogical instrument must hold the following elements according to (Johnson and Johnson 2002).

1. Clearly perceived positive interdependence;

2. Clearly perceived individual accountability and personal responsibility to achieve the group's goals;

3. Considerable promotive (face-to-face) interaction;

4. Frequent use of the relevant interpersonal and small-group skills;

5. Frequent and regular group processing of current functioning to improve the group's future effectiveness.

The first element, positive interdependence, is fundamental to create a cooperative environment. It reflects the principles of social interdependence theory; this theoretical background affirms that the way individuals interact is determined by the form their social interdependence is framed.

Furthermore, the collective goal can only be attained with the success of all group participants, for such, another element named individual accountability emerges. Inasmuch as individuals are interdependent, it is necessary for each to be accountable and all parts have to fulfill their initial demand to avoid group impairment. Individual accountability occurs as individual performance is evaluated and results are shared. This happens so students can stimulate the elaborative process and later, the produced knowledge is distributed with the group (Lopes and Silva 2009).

In this sense, it is vital for students to interact face-to-face. Some activities and interpersonal dynamics only occur when students get involved with each other's learning. Thus, another element of Cooperative Learning arises, promotive interaction. It takes place when members stimulate one another to participate in the execution of tasks, including oral explanations on how problems might be solved, discussions about the nature of concepts to be learnt and methods to teach their peers (Johnson and Johnson 2002).

In order to students become able to overcome adversities and conflicts in a constructive way, another element is also demanded: interpersonal skills. For instance, some of these skills are listening carefully; waiting for the correct time to talk; criticizing ideas, not people; sharing ideas; and, helping others to feel inserted in the process. These skills 
are essential for the group to be prosperous, as they enable members to progress actively, critically and engaged in society, besides contributing for the interaction between students' cultures, a constituting factor of academic success in Cooperative Learning (Johnson and Johnson 2002).

Group processing is also considered one of the most relevant elements of CL. In the end of the process, the group has to get together and talk about what procedures and outcomes were positive and negative; in addition, the group should suggest ideas to maximize collective learning. Group processing must comprise questions that foment self-evaluation, regarding the use of interpersonal skills and the practice of promotive interaction. This moment permits groups to observe the effectiveness of their cooperation. As those efforts are systematically repeated, these groups improve teamwork and encourage participation, reducing conflicts and developing students' autonomy (Johnson et al. 2004).

Prince (2004) highlights that the most commonly found model on Cooperative Learning is the one presented by Johnson, Johnson and Smith, proposed in 1998, due to its five incorporated principles.

The study from Gillies and Boyle (2010) about the perception teachers while implementing the Cooperative Learning methodology evidenced that all interviewees saw the method positively and this use enabled lessons to be better managed and structured. Regarding its challenges, these teachers reported that socialization should occur between groups and that the time for management and organization necessary to implement Cooperative Learning were issues as well. Moreover, they stressed the challenge to compose groups and the kind of task necessary to motivate students.

Buchs et al. (2011) state that there is little doubt about the effects of Cooperative Learning, given that a considerable number of meta-analysis over the years demonstrated that Cooperative Learning has beneficial effects on students' self-esteem, interactions and learning.

\section{University extension}

University extension implies working processes of education based on a critical form of teaching and learning, perceiving the social context where the extension program happens. By adopting this perspective, it is possible to interchange popular and academic knowledge, building up a relationship of criticism and interchange of experiences (Cruz et al. 2011). The critical pedagogy approach is underpinned on freedom between educator and students, wherein learning is built bilaterally: the educator teaches and learns together with his or her students (Freire 1979).

The university extension is ought to be grounded on the critical pedagogy conceptual model, given that is based on dialogue, a horizontal relationship, wherein teacher and student are able to make and remake their trajectories. As students' experiences are respected through a constant dialogical process, the chances of a successful effort in popular contexts become more realistic, once the action values the social context where it happens (Cruz et al. 2011).

The theoretical perspective brought forward until now is important as it intended to investigate how interactions between university, community and PRECE has been 
beneficial to all parts. Hence, to explain how these elements have been operationalized and later analyzed the next section explains the methodology guiding this research.

\section{Methods}

This research qualifies as descriptive once it seeks to describe a social phenomenon, identifying its characteristics (Collis and Hussey 2005). Moreover, this study is qualitative and adopts as research strategy the case study of PRECE following the criteria proposed by Yin (2010).

Data were collected through semi-structured interviews and related documents to the case (print newspapers and magazines) made available by interviewees. Furthermore, information available in PRECE and PACCE's (the Cooperative Learning extension program based on PRECE's experience) websites were added to the databank. The data collected in documents and websites were useful so that researchers could improve understanding about the case.

Individual interviews in person, instead of focal groups, were employed in this study. The number of participants was defined according to their availability. Interviewees' lines were presented in the analysis as quotes to illustrate how the person answered the question, according to Table 1.

The interview script aimed to contemplate general questions in its first block, which allowed contextualizing PRECE and Cooperative Learning in UFC appropriately; then, the second group of questions was dedicated specifically to the five constituting elements of Cooperative Learning listed by Johnson and Johnson (2002). Interviewees were advised to talk freely, followed by some complementary interventions when the need to deepen the ongoing discussion emerged.

In this sense, the questions used in the semistructured interviews were sorted according to the literature related to Cooperative Learning. Besides a general question requesting the interviewee to foreground PRECE's trajectory, other five were made, concerning each Johnson and Johnson's (2002) Cooperative Learning element. Their focus was to reach the interviewee's perception on how the theory was operationalized through PRECE's activities and its partnerships.

\section{Table 1 Data collection instrument for the interviews}

\begin{tabular}{|c|c|}
\hline \multicolumn{2}{|c|}{ Elements for Cooperative Learning_Johnson and Johnson (2002) } \\
\hline Clearly perceived positive interdependence & $\begin{array}{l}\text { How is it established the relationship of interdependence } \\
\text { between students and other actors involved in the } \\
\text { Program? (exchanges, cooperation) }\end{array}$ \\
\hline Considerable promotive (face-to-face) interaction & $\begin{array}{l}\text { How is it established the relationship of incentive } \\
\text { between group members to reach defined objec- } \\
\text { tives? }\end{array}$ \\
\hline $\begin{array}{l}\text { Clearly perceived individual accountability and personal } \\
\text { responsibility to achieve the group's goals }\end{array}$ & How students' individual accountability is fostered? \\
\hline $\begin{array}{l}\text { Frequent use of the relevant interpersonal and small- } \\
\text { group skills }\end{array}$ & $\begin{array}{l}\text { How are interpersonal abilities explored in small groups } \\
\text { in order to reach mutual objectives? }\end{array}$ \\
\hline $\begin{array}{l}\text { Frequent and regular group processing of current func- } \\
\text { tioning to improve future effectiveness }\end{array}$ & How does the group evaluate its work? \\
\hline
\end{tabular}

Source: Elaborated by the authors based on Johnson and Johnson (2002) 
To analyze the data collected, the guidelines for qualitative research provided by Creswell (2010) were followed. At first, data were organized to be read and studied. The analysis began through codification and separation processes of information in blocks according to the questionnaire parts and interviewees. In the end, the categories of analysis were evidenced based on the constituting elements of Cooperative Learning as defined by Johnson and Johnson (2002), which permitted the interpretation and extraction of meaning from the data.

\section{Actors interviewed}

The data were collected in Fortaleza between March and April of 2015. The ones chosen to be heard came from PRECE and UFC's Cooperative Learning Program. The process totalized six interviewees: PRECE's co-founder and articulator, PRECE's coordinator of social communication, the President of the Popular Cooperative School in Pentecoste, a UFC Student participating of the PACCE, the Vice-President of the Popular Cooperative School in Pentecoste, the Director of the Cooperative Learning Division at the Coordination of Formation and Cooperative Learning (COFAC in Portuguese) at the UFC.

It was chosen not to focus on the beneficiaries. The justification for such choice related to one of this research's objectives, which was to investigate elements of Cooperative Learning being employed, and it was believed that the managerial group would better explain these definitions.

\section{Case presentation, data analysis and results}

The data collected and results achieved are analyzed in this section, making reference to each of the specific objectives previously defined, aiming at fulfilling the general objective. It is emphasized that part of the information presented here were retrieved from PRECE's website (http://www.prece.ufc.br) and from PACCE/COFAC blog's (http:// www.pacceufc.blogspot.com.br) and were completed by interviewees' talks.

\section{Program of Education in Cooperative Cells (PRECE)}

Program of Education in Cooperative Cells (PRECE-Programa de Educação em Células Cooperativas, in Portuguese) began in 1994, in a rural community called Cipó in Pentecoste, located in the semiarid region of Ceará. At that time, seven youngsters out of the correct school age decided to start studying in an old manioc mill. At first, they were helped by the community and by the PRECE's co-founder and articulator, who had also been born in Cipó and returned to the community every weekend to collaborate with them. Despite the precarious conditions, in a solidary and cooperative way, their first result was achieved in 1996: one of those seven students, Francisco Antônio Alves Rodrigues, was approved in first place to study Education at the Federal University of Ceará.

In the early 2000s, PRECE started to gain scale, as it became known by the communities surrounding Cipó, where its activities had been centered until then. Students from urban and rural areas began to use their own means to go to Cipó and study together, trying to accomplish the same as Francisco Antônio had performed.

PRECE's co-founder and articulator suggested the students to take to their urban or rural communities the organizational skills and methodology they had cooperatively 
learnt. Hence, young people who used to study together in small groups founded the first Escolas Populares Cooperativas (EPCs-Popular Cooperative Schools in Portuguese).

A group of students, who get together to share knowledge, operates a study "cell". There is no formal teacher; students themselves become facilitators; they support each other and overcome deficiencies as a group, insofar as they prepare to go to university. After being approved, these students return to their communities to manage the local EPCs and help monitoring the study cells. In their communities, new university students transform into exemplars of overcoming to others, motivating their peers to go to college as well.

Currently, the initiative has still been managed by its own students. To date, the program has been able to place about 600 hundred students in different universities, but mostly in the Federal University of Ceará. These individuals now come from 15 EPCs that were started in four different municipalities in the Cearás semiarid region: Apuiarés, Paramoti, Pentecoste and Umirim.

\section{PRECE as a Cooperative Learning Program}

In 1998, one of PRECE's co-founder articulated with the Federal University of Ceará (UFC) and the initiative became an extension project, status that occupies to date. In the beginning, this partnership provided the project transportation to students, who were in the Fortaleza campi, back to their communities. Furthermore, this collaboration was the seed of what later would become a broader UFC project called PACCE, which has been operating with Cooperative Learning.

The project's main objective was to harness PRECE's methodology to reach similar results. Students coming from PRECE did not evade university, since they counted on the solidarity network of their friends as well as the assisting structure from the Program itself. Evasion has been a problem at UFC, especially in courses requiring substantial previous mathematical background. As a result of these deficiencies, students quit, missing the opportunity of attaining a college degree.

Hence, the Cooperative Learning Program in Student Cells (PACCE-Programa de Aprendizagem Cooperativa em Células Estudantis, in Portuguese) started in 2009 with the main purpose of encouraging students to form small study groups to help each other in improving results in more difficult subjects. The objective was to reduce evasion indices.

Professor Manuel Andrade made this chain, this bond between PRECE and University. It was also because of PRECE's results that the university started to see this movement; many people came from the countryside, in need for residence, very hardworking people in many courses with very low evasion rates. That drew much attention (UFC Student participating at the PACCE).

PACCE stimulates the creation of cells of mutual assistance among undergraduate students; the bonds generated within these small groups would help participants to face academic and extra-academic challenges, contributing to achieving better performance and approval in their courses.

The program is carried out by the Coordenadoria de Formação e Aprendizagem Cooperativa (COFAC_Coordination of Formation and Cooperative Learning in Portuguese), 
which is connected to the Office of Undergraduate Studies at the UFC. The programs have 250 students on scholarship from a variety of courses and campi, and besides receiving training about the methodology; these students are responsible for organizing a cell that has to develop a learning project on a topic of their free choice. It is demanded that $12 \mathrm{~h}$ of activities to be fulfilled every week, and as an incentive the students receive R \$ 400 (US\$133.33) during 10 months.

PACCE's activities have been supervised and monitored by the Coordenadoria de Formação e Aprendizagem Cooperativa (COFAC-Formation and Cooperative Learning Coordination in Portuguese). COFAC is an integrating part of UFC and it is responsible for defining, proposing, organizing and coordinating actions oriented to continuous training of UFC professors, in a dialogical, cooperative and meaningful perspective, aiming, in parallel, to improve undergraduate education.

\section{PRECE/PACCE alignment with Cooperative Learning elements}

In the beginning of its activities, according to one of PRECE's co-founder and articulator, the Cooperative Learning methodology was not known. It was only in 2007, when PRECE's main founder went to the USA for his post-doctoral studies that he had contact with the methodology, which was later used to systematize PRECE's work. It was then that the elements of Cooperative Learning as suggested by Johnson and Johnson (2002) were incorporated. In this sense, the interviewees' discourse evidenced the five core elements of the methodology, presented in the analysis that follows.

\section{Positive interdependence}

Interviewees' speech highlighted certain key features regarding positive interdependence, which corroborated with aspects related to this element as proposed by Johnson and Johnson (2002).

Interaction among students is a central part of the methodology, a fundamental principle of Cooperative Learning, providing a sense of cooperation and collective construction to the involved in the process.

The student doesn't go there just to receive, but he can participate, he can interact in a way that enables him to contribute even with the next workshop. Because there is too much of them in the process, they make the workshop, and then according to what happens; they evaluate and then can add improvements to the next one. So, I think it has much to do with students' participation, something that doesn't happen in the traditional method, right? What I teach is always bottom-up, that is the issue getting changed with the process. I think the student contribute with that, too. So, I think there is an interdependence, an interference in this moment (PRECE's coordinator of social communication).

Positive interdependence also occurs through examples that each individual involved in the Program gives to their peers.

When students enter PACCE they undertake many training courses, but there is also the Pedagogy of Example. They know PRECE's history, which is already a great stimulus, so they can see seven rednecks from Cipó that together were able to reach university. It is in the practice that they are able to get this understanding: "I need 
you and you need me" (UFC Student participating of the PACCE).

Furthermore, interdependence is described as a responsibility from the ones involved. In the case that some of the members do not commit with activities defined, there might be a break, which will harm the working progress, affecting everybody. Thus, dependence occurs in a horizontal perspective of shared responsibilities and egalitarian cooperation.

They have their own responsibilities, to go to the classes, to the activities, to the meetings, as we have ours and we can only do our work if they do theirs, and vice versa. So, this interdependence is always present (Vice-President of the Popular Cooperative School in Pentecoste).

The PACCE is a program totally run by students; the interdependence relationship is very cool because they can, in a certain way, transmit values and challenges from student to student. Not in the teacher-student [traditional] relationship in which it should exist an established hierarchy, creating dependence. The interdependence relationship that takes place, according to the theory, is a positive one. The negative interdependence would be competition, the positive, cooperation and the neutral, individualistic (Director of the Cooperative Learning Division at Coordination of Formation and Cooperative Learning at the UFC).

\section{Individual accountability and personal responsibility}

Individual accountability is introduced as a fundamental element to reach collective goals. Each member's performance, shared with their peers, will result in effects that might be beneficial or harmful.

The individual accountability is highly valued and it is through it that you can show how the absence of it is negative. It happens that some people miss the study in groups, they forget handing out some activity and in these negative situations we are able to demonstrate that during that period of time the group was not able to meet its goals because some people were absent with no justification. So, we say: notice how important you are to the group! (UFC Student participating of the PACCE).

The presence of working groups and previous preparation for sharing the learnt knowledge is essential for the process. The involved are constantly reminded that failing in committing at any of the steps would imply in a negative collective effect.

They always have to study because they know that when they arrive at the group study in the cell, they will have to contribute with the cooperative learning through the knowledge they acquired, so they have to have the individual accountability of studying at home (Vice-President of the Popular Cooperative School in Pentecoste).

It starts by the enrolment the students do to participate in the selection because he needs to present the project he will develop. When he participates in the selection, he realizes that our scholarship is oriented to the individual accountability, if he does not do it, the collective goal will not be reached. When he goes to the training courses, for example, in all workshops there are the distribution of individual 
responsibilities (Director of the Cooperative Learning Division at Coordination of Formation and Cooperative Learning at the UFC).

\section{Promotive (face-to-face) interaction}

Concerning the promotive face-to-face interaction, interviewees emphasized the importance of sharing efforts and responsibilities each one of them has for mutual learning. All participants are in charge of offering knowledge reciprocally by promoting interactive exchanges of insights.

The collective goal is an issue worked constantly, and through this goal, it is possible to have positive and collective interdependence, in the sense that we will get there if we all walk together (UFC Student participating of the PACCE).

Interactions in learning cells occur by an intense exploration of Cooperative Learning elements, inasmuch as each one of the students and teachers becomes responsible for a job in the group. Personal and direct interaction among members takes place in a clear way granted that everyone's roles are plainly defined.

We advise that cell be composed of five people at best, because more than five normally leaves some idle in the group. In this team, there is the coordinator, the time controller, the noise controller and the guardian of the 'cooperation contract,' which oversees the noise and phone answering, for instance. The contents are divided in parts for each one and the sum of these parts is the final collective goal, which can be the resolution of 10 questions, for example (PRECE's co-founder and articulator).

Students with their own experiences, with discussions, with exchanging ideas, stimulate each other (Director of the Cooperative Learning Division at Coordination of Formation and Cooperative Learning at the UFC).

\section{Use of interpersonal and small-group skills}

Regarding the interpersonal abilities required for Cooperative Learning to happen, the identification of those skills occurs in the beginning of group work, when participants foreground the strengths to be explored collaboratively.

If they have competence to more than one discipline, so they go to help their peers in those subjects, so each student completes what is missing for their friends, and they keep helping one another (PRECE's Coordinator of Public Relations).

There [in the groups], we learn these social abilities. To know how to listen to your friend, to give an opinion, to criticize, to give ideas, some things they learn with time, the experienced facilitators keep teaching, and practicing with them, there are no specific training courses for that (Director of the Popular Cooperative School of Pentecoste).

During the courses, interpersonal abilities keep being stimulated, because they represent a fundamental element in the collaborative work. In addition, the exchanges 
promoted motivate students' sense and acknowledgement of usefulness and relevance in the group.

We have a workshop called 'interpersonal abilities' wherein a training course takes place and we study, at least, twenty-five abilities. These skills keep being developed day-by-day, especially during the training courses and this development keeps happening in the interactions and then students try to apply these skills to their cells as well (PACCE's Coordinator).

We have always esteemed personal abilities, and what he is willing to learn. We always look for the person's strengths, so through these strengths he can contribute to the group (Vice-Director of the Popular Cooperative School of Pentecoste).

\section{Group processing}

Group processing happens in the end of every activity, as participants are encouraged to think about their actions individually and collectively. This evaluation process connects the role in the execution of tasks with personal responsibilities. The advances and obstacles of the process are outlined in this moment; furthermore, after identifying these issues, the participants engage in a debate to improve how dynamics may take place in the future.

The group is stimulated to shape itself in a way that reaches goals. Normally, these goals are connected to the access to university or even to their schools, the cooperative learning, right? And there is a group that monitors these groups through records, reports... so they follow in practice what is happening with this group step by step. How are they gathering? How often? What difficulties do they have? So, even from a distance, this team tries as hard as it can to keep this monitoring (PRECE's coordinator of social communication).

The evaluation does not depend only on the learning itself, but also on the social performance, on how they have interacted, it is an evaluation of how the whole process happened (PRECE's co-founder and articulator).

The interviewees' speech highlighted that the assessment, besides being related to desired goals, is also involved with the entire development of efforts, until it reaches the final objective set by the group ex ante.

We assess the process. How it was, how the person felt during his studies, if the person felt well, if she felt valued, if she could live the conflicts in the group and if these conflicts indeed contributed, if it was possible to cope with them. The group processing assess not only the results, but also the process (UFC Student participating of the PACCE).

There is an academic evaluation, which is written, always in the end of the cooperative learning process. There is the written evaluation of content and there is the group process, which is how the whole study was carried out, how was the group process in all its aspects (PRECE's co-founder and articulator). 
Questioning rights and wrongs during the assessment in front of the whole group, in the way displayed above, promotes greater concern with the tasks delegated to each participant. The group is aware that not fulfilling the plan leads to negative consequences for all the parts. In this sense, group processing is linked with the other pillars of Cooperative Learning, although they were conveyed here separately for textual purposes.

Group processing means that after some activity we dedicate some time to perform an assessment of what was done, and we start from three very basic questions: How nice?! How bad?! What about...? And each one in the group needs to answer these questions about that practice. So, everybody learns how to evaluate one another in a very simple way (Director of the Cooperative Learning Division at Coordination of Formation and Cooperative Learning at the UFC).

This analysis sought to foreground the exploration of data collected based on the five elements of Cooperative Learning proposed by Johnson and Johnson (2002). The contribution of this study lies in bringing forward a successful initiative, developed in an extremely disadvantaged region from the Brazilian northeast. In this sense, foregrounding this initiative is important so others can be highlighted too. Regarding suggestions for future research, it is recommended that other sources on Cooperative Learning be explored as well as other representative cases such as the one introduced in this paper.

\section{Conclusions}

Cooperative Learning can be used as an empowering methodology, in a way wherein the ones involved can learn by teaching their peers and being taught simultaneously. These exchanges enable a kind of learning through social relationships, motivated by collaborative bonds. Freire (1979) supports this view, as he emphasizes the role of education's prominent political character as a strategy to change the world. Teaching would be more than simple training once the educator must stimulate students' criticism and willingness to learn.

The initiative sponsored by the Programa de Educação em Células Cooperativas (PRECE), incorporated as an extension program in the Federal University of Ceará, foregrounds the advantages of learning cooperatively to foment an integrative and collaborative culture. CL has proven to be a useful tool to achieve meaningful learning experiences and nurture social competences (Vieira 2011).

Analyzing positive interdependence, individual accountability, the promotion of faceto-face interactions, and group processing, in which processes and results are assessed, it was possible to identify how these efforts are being developed in PRECE's case.

Overall, this article brought forward PRECE as an initiative that, since the 1990s, has benefited youngsters by using collaborative study techniques to place these individuals at public universities. It has also foregrounded how it was integrated to the UFC, fact that made possible for the university to improve students' performance, reducing evasion rates. Finally, it was emphasized how the integration of Cooperative Learning elements yielded in positive results for both PRECE and the UFC.

Furthermore, a wider data collection is recommended as a suggestion for future research. In this sense, students from other cities served by the Program could be heard to explore PRECE more closely. Finally, the further study and comparison with similar 
educational programs could also answer other research questions not contemplated here.

\section{Authors' contributions}

BSL wrote the parts of the introduction, theoretical backgrounds, went to do the field research and performed the interviews that enabled this study. He also participated in elaborating the methodology. ACAAS also wrote the introduction, theoretical backgrounds and assisted in creating the methodology. She helped in analysing the data and was essential to discuss our findings. JCLSF was the senior researcher in this study and supervised the work and helped to analyse and discuss the data as well as revised the paper after its conclusion for any possible consistency incongruencies. In addition, he provided important insights on how to interview the social actors involved. All authors read and approved the final manuscript.

\section{Author details}

${ }^{1}$ Universidade Federal do Ceará, Avenida da Universidade, 2431 - Benfica, Fortaleza, Ceará, Brazil. ${ }^{2}$ Universidade Federal do Rio Grande do Sul, Rua Washington Luís, 855 - Centro, Histórico, Porto Alegre, Rio Grande do Sul, Brazil.

\section{Acknowledgements}

The authors thank all interviewees for their participation and the concession of such valuable data.

\section{Competing interests}

The authors declare that they have no competing interests.

Received: 30 September 2015 Accepted: 25 February 2016

Published online: 12 March 2016

\section{References}

Artzt A, Newman C (1997) How to use cooperative learning in the mathematics classroom, 2nd edn. The National Council of Teachers of Mathematics Inc., Reston

Buchs C, Gilles I, Dutrevis M, Butera F (2011) Pressure to cooperate: Is positive reward interdependence really needed in cooperative learning? Br J Educ Psychol 81:135-146

Collis J, Hussey RC (2005) Pesquisa em administração: um guia prático para alunos de graduação e pós-graduação, 2nd edn. Bookman, Porto Alegre

Creswell J (2010) Qualitative inquiry and research design: choosing among five approaches. Sage, Thousand Oaks, CA

Cruz BPA, Melo WDS, Malafaia FCB, Tenório FG (2011) Extensão universitária e responsabilidade social: 20 anos de experiência de uma instituição de ensino superior. Revista de Gestão Social e Ambiental 5(3):3-16

Freire P (1979) Extensão ou Comunicação?, 4th edn. Paz e Terra, Rio de Janeiro

Gillies RM (2003) Structuring cooperative group work in classrooms. Int J Educ Res 39(1-2):35-49

Gillies RM, Boyle M (2010) Teachers' reflections on cooperative learning: issues of implementation. Teach Teach Educ 26(4):933-940

Hennessey A, Dionigi RA (2013) Implementing cooperative learning in Australian primary schools: generalist teachers' perspectives. Issues Educ Res 23(1):52-68

Hsiung CM, Lou SJ, Lin CC, Wang PL (2014) Identification of dysfunctional cooperative learning teams and troubled individuals. Br J Educ Technol 45(1):125-135

Jaguaribe H (2001) Um estudo crítico da História. Paz e Terra, São Paulo

Johnson DW, Johnson RT (1989) Cooperation and competition: theory and research. Interaction Book Company, Edina Johnson DW, Johnson RT (2002) Learning together and alone: overview and meta-analysis. Asia Pac J Educ 22:95-105

Johnson DW, Johnson RT, Smith K (2004) Constructive controversy: effective techniques for stimulating college students. Change 32(1):28-37

Leikin R, Zaslavsky O (1999) Cooperative learning in mathematics. Math Teach 92(3):240-246

Lopes J, Silva HS (2009) A aprendizagem cooperativa na sala de aula: um guia prático para o professor. Lidel, Lisboa

Peterson SE, Miller JA (2004) Comparing the quality of students' experiences during cooperative learning and largegroup instruction. J Educ Res 97(3):123-133

PRECE—Programa de Educação em Células Cooperativas (2015) Quem somos? Retrieved from: http://www.prece.ufc $\mathrm{br} /$ ?page_id $=368$

Prince MJ (2004) Does active learning work? A review of the research. J Eng Educ 93(3):223-231

Stahl R (1994) The Essential elements of cooperative learning in the classroom. ERIC Digest ED370881

Vieira CPC (2011) Aprendizagem cooperativa no treino das competências sociais. 2011. 153 f. Dissertação (Mestrado em Psicologia da Educação)—Universidade de Trás-os-Montes e Alto Douro,Vila Real

Yin RK (2010) Estudo de caso, 2nd edn. Bookman, Porto Alegre 